\title{
Front Matter: Volume 7951
}

"Front Matter: Volume 7951," Proc. SPIE 7951, Laser Refrigeration of Solids IV, 795101 (25 February 2011); doi: 10.1117/12.890414

SPIE. Event: SPIE OPTO, 2011, San Francisco, California, United States 


\section{PROCEEDINGS OF SPIE}

\section{Laser Refrigeration of Solids IV}

Richard Epstein

Mansoor Sheik-Bahae

Editors

26-27 January 2011

San Francisco, California, United States

Sponsored and Published by

SPIE

Volume 7951

Proceedings of SPIE, 0277-786X, v. 7951

SPIE is an international society advancing an interdisciplinary approach to the science and application of light. 
The papers included in this volume were part of the technical conference cited on the cover and title page. Papers were selected and subject to review by the editors and conference program committee. Some conference presentations may not be available for publication. The papers published in these proceedings reflect the work and thoughts of the authors and are published herein as submitted. The publisher is not responsible for the validity of the information or for any outcomes resulting from reliance thereon.

Please use the following format to cite material from this book:

Author(s), "Title of Paper," in Laser Refrigeration of Solids IV, edited by Richard Epstein, Mansoor Sheik-Bahae, Proceedings of SPIE Vol. 7951 (SPIE, Bellingham, WA, 2011) Article CID Number.

ISSN 0277-786X

ISBN 9780819484888

Published by

SPIE

P.O. Box 10, Bellingham, Washington 98227-0010 USA

Telephone +1 3606763290 (Pacific Time) · Fax +1 3606471445

SPIE.org

Copyright (C) 2011, Society of Photo-Optical Instrumentation Engineers

Copying of material in this book for internal or personal use, or for the internal or personal use of specific clients, beyond the fair use provisions granted by the U.S. Copyright Law is authorized by SPIE subject to payment of copying fees. The Transactional Reporting Service base fee for this volume is $\$ 18.00$ per article (or portion thereof), which should be paid directly to the Copyright Clearance Center (CCC), 222 Rosewood Drive, Danvers, MA 01923. Payment may also be made electronically through CCC Online at copyright.com. Other copying for republication, resale, advertising or promotion, or any form of systematic or multiple reproduction of any material in this book is prohibited except with permission in writing from the publisher. The CCC fee code is $0277-786 \mathrm{X} / 11 / \$ 18.00$.

Printed in the United States of America.

Publication of record for individual papers is online in the SPIE Digital Library.

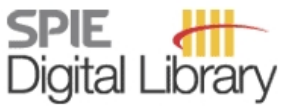

SPIEDigitalLibrary.org

Paper Numbering: Proceedings of SPIE follow an e-First publication model, with papers published first online and then in print and on CD-ROM. Papers are published as they are submitted and meet publication criteria. A unique, consistent, permanent citation identifier (CID) number is assigned to each article at the time of the first publication. Utilization of CIDs allows articles to be fully citable as soon they are published online, and connects the same identifier to all online, print, and electronic versions of the publication. SPIE uses a six-digit CID article numbering system in which:

- The first four digits correspond to the SPIE volume number.

- The last two digits indicate publication order within the volume using a Base 36 numbering system employing both numerals and letters. These two-number sets start with 00, 01, 02, 03, 04, $05,06,07,08,09,0 A, 0 B \ldots 0 Z$, followed by 10-1Z, 20-2Z, etc.

The CID number appears on each page of the manuscript. The complete citation is used on the first page, and an abbreviated version on subsequent pages. Numbers in the index correspond to the last two digits of the six-digit CID number. 


\section{Contents}

$\checkmark \quad$ Conference Committee

\section{SESSION 1 APPLICATIONS OF SOLID-STATE LASER COOLING}

795102 USAF space sensing cryogenic considerations (Invited Paper) [7951-01]

E. N. Pettyjohn, Air Force Research Lab. (United States)

795103 Progress toward sub-100 Kelvin operation of an optical cryocooler [7951-02]

D. V. Seletskiy, Air Force Research Lab. (United States) and The Univ. of New Mexico (United States); R. I. Epstein, M. Sheik-Bahae, Air Force Research Lab. (United States)

795105 Experimental evidence for laser cooling of Yb:YLF to 120 Kelvin [7951-04]

S. D. Melgaard, D. Seletskiy, The Univ. of New Mexico (United States); A. Di Lieto, M. Tonelli, Univ. di Pisa (Italy); M. Sheik-Bahae, The Univ. of New Mexico (United States)

795106 Local internal and bulk optical cooling in Nd-doped crystals and nanocrystalline powders revisited (Invited Paper) [7951-05]

A. J. Garcia-Adeva, Escuela Técnica Superior de Ingeniería (Spain); R. Balda, Escuela Técnica Superior de Ingeniería (Spain) and Ctr. de Física de Materiales CSIC-UPV/EHU and Donostia International Physics Ctr. (Spain); M. Al Saleh, S. Garcia-Revilla, Escuela Técnica Superior de Ingeniería (Spain); J. Fernandez, Escuela Técnica Superior de Ingeniería (Spain) and Ctr. de Física de Materiales CSIC-UPV/EHU and Donostia International Physics Ctr. (Spain)

\section{SESSION 2 HEAT REMOVAL AND RADIATIONAL BALANCED LASERS}

795109 Conceptual study of a fiber-optical approach to solid-state laser cooling (Invited Paper) [7951-08]

D. T. Nguyen, NP Photonics (United States); C. Shanor, College of Optical Sciences, The Univ. of Arizona (United States); J. Zong, W. Tian, Z. Yao, J. Wu, NP Photonics (United States); J. Weiss, College of Optical Sciences, The Univ. of Arizona (United States); R. Binder, College of Optical Sciences, The Univ. of Arizona (United States) and The Univ. of Arizona (United States); A. Chavez-Pirson, NP Photonics (United States)

\section{SESSION 3 OPTOMECHANICAL AND SEMICONDUCTOR COOLING}

7951 OB Efficient optomechanical cooling in one-dimensional interferometers (Invited Paper) [7951-10]

P. Domokos, Research Institute for Solid-State Physics and Optics (Hungary); A. Xuereb,

P. Horak, T. Freegarde, Univ. of Southampton (United Kingdom) 
7951 OD GaAs/GalnP double heterostructure characterization for laser cooling of semiconductors [7951-12]

C. Wang, C.-Y. Li, M. P. Hasselbeck, T. Rotter, K. Malloy, M. Sheik-Bahae, The Univ. of New Mexico (United States); J. Olson, National Renewable Energy Lab. (United States)

\section{SESSION 4 LASER COOLING IN RARE-EARTH-DOPED SOLIDS}

7951 OE Laser cooling in materials with high concentration of erbium (Invited Paper) [7951-13]

Z. Hasan, Z. Qiu, J. Lynch, Temple Univ. (United States)

7951 OG Breaking the low phonon energy barrier for laser cooling in rare-earth doped hosts [7951-15] G. Nemova, R. Kashyap, École Polytechnique de Montréal (Canada)

$7951 \mathrm{OH}$ Effects of photon transport, emission saturation, and reflection losses on thermophotonic cooling [7951-16]

J. Oksanen, J. Tulkki, Aalto Univ. (Finland)

\section{SESSION 6 POSTER SESSION}

7951 ol Mach-Zehnder interferometric measurement of laser heating/cooling in Yb ${ }^{3+}$ : YAG [7951-17] C. Farley III, B. R. Reddy, Alabama A\&M Univ. (United States)

7951 0J Sensitive thermal reflectance measurement for laser cooling applications [7951-18] M. Ghasemkhani, The Univ. of New Mexico (United States); D. Seletskiy, Air Force Research Lab. (United States) and The Univ. of New Mexico (United States); M. Sheik-Bahae, The Univ. of New Mexico (United States)

Author Index 


\title{
Conference Committee
}

\author{
Symposium Chair
}

Liang-Chy Chien, Kent State University (United States)

Symposium Cochairs

E. Fred Schubert, Rensselaer Polytechnic Institute (United States)

Klaus P. Streubel, OSRAM GmbH (Germany)

Program Track Chair

Zameer U. Hasan, Temple University (United States)

Conference Chairs

Richard Epstein, The University of New Mexico (United States)

Mansoor Sheik-Bahae, The University of New Mexico (United States)

Program Committee

Rolf H. Binder, College of Optical Sciences, The University of Arizona (United States)

Steven R. Bowman, U.S. Naval Research Laboratory (United States)

Zameer U. Hasan, Temple University (United States)

Jacob B. Khurgin, The Johns Hopkins University (United States)

Roberto Onofrio, Dartmouth College (United States)

Yong-Hang Zhang, Arizona State University (United States)

\section{Session Chairs}

1 Applications of Solid-State Laser Cooling

Kent L. Miller, Air Force Office of Scientific Research (United States)

2 Heat Removal and Radiational Balanced Lasers

Joaquín Fernández, Universidad del País Vasco (Spain)

3 Optomechanical and Semiconductor Cooling

Jacob B. Khurgin, The Johns Hopkins University (United States)

$4 \quad$ Laser Cooling in Rare-Earth-doped Solids

Erin Pettyjohn, Air Force Research Laboratory (United States) 
Downloaded From: https://www.spiedigitallibrary.org/conference-proceedings-of-spie on 26 Apr 2023

Terms of Use: https://www.spiedigitallibrary.org/terms-of-use 